\title{
Studies on Variability, Heritability and Genetic Advance in parental lines of Hybrid Rice (Oryza sativa L.)
}

\author{
Chinnapa Reddy Allam ${ }^{1,3}$, T.E. Nagaraja ${ }^{2}$ and N. Shivakumar ${ }^{3}$ \\ ${ }^{1}$ Department of Genetics and Plant Breeding, UAS, GKVK, Bengaluru 560065, India \\ ${ }^{2}$ AICRP on Pigeon pea, UAS, GKVK, Bengaluru 560065, India \\ ${ }^{3}$ Hybrid Rice Section, ZARS, V.C. Farm, Mandya 571401, India \\ *Corresponding author
}

\section{A B S T R A C T}

\section{Keywords \\ Variability, \\ Heritability and \\ Genetic advance, \\ Rice \\ Article Info \\ Accepted: \\ 15 August 2019 \\ Available Online: \\ 10 September 2019}

Genetic variability, genotypic and phenotypic coefficients of variation, heritability and genetic advance for twenty-one characters in twenty-eight parental lines of hybrid rice were studied. The analysis of variance revealed highly significant differences for all the characters among the genotypes. The magnitude of differences between PCV and GCV was relatively low for all the traits, indicating less environmental influence. The estimates of genotypic and phenotypic coefficients of variation (GCV and PCV) were high for spikelets per panicle, flag leaf area, days to $50 \%$ flowering, days to maturity and grain yield per plant. Heritability and genetic advance were high for all the characters except pollen fertility which had low genetic advance along with high heritability indicating the involvement of additive and non-additive type of gene action respectively in controlling this character.

\section{Introduction}

Rice (Oryza sativa L.), belongs to the family Graminae, recognized as "millennium crop" expected to contribute towards food security in the world, as it is one of the staple cereal crops of the world and a primary source of food for more than half the world's population. With an alarming increase in the population throughout the world, the demand for rice will continue to increase in near future. Therefore, rice breeders across the world aim at increasing the grain yield of rice. A better understanding of the relationship between grain yield and its component traits becomes necessary for making an efficient selection for the development of new varieties with improved economically important traits. The knowledge of heritability and genetic variability is a prerequisite for carrying out selection-based improvement. The information about these help in the breeding programme by broadening the gene pool of rice and gives an indication about the efficiency of transformation of characters into future generations respectively. In any crop species setting the breeding objective to improvement of crop yield is prime importance. 
Understanding of nature and magnitude of genetic variation governing the inheritance of relatively quantitative traits like yield and attributing traits are essential. Plant breeder has to analyze certain genetic variability parameters like Genetic coefficient of variation (GCV), phenotypic coefficient of variation (PCV), Heritability, and Genetic Advance of various economic important quantitative traits to plan future crop improvement programmes. Genetic variability plays an important role in study and identification of promising rice genotypes. Heritability is the heritable portion of phenotypic variance. It is a good index of the transmission of the characters from parents to offspring (Falconer, 1981). Genetic advance is also of considerable importance because it indicates the magnitude of the expected genetic gain from one cycle of selection (Hamdi et al., 1992). Hence the present investigation was undertaken to study the genetic variability, heritability and genetic advance in some parental lines of hybrid rice.

\section{Materials and Methods}

A field experiment was conducted with 28 parental lines of hybrid rice, developed by pedigree breeding method, in a Randomized Block Design with two replications during kharif 2015 at Zonal Agriculture Research Station(Z.A.R.S), V. C. Farm, Mandya, Karnataka. Twenty five days old seedlings were transplanted with a spacing of $15 \mathrm{~cm}$ and $15 \mathrm{~cm}$ between rows and plants, respectively. Five representative plants for each genotype in each replication were randomly selected to record observations on days to $50 \%$ flowering [DFF], days to maturity [DM], plant height $[\mathrm{PH}](\mathrm{cm})$, tillers per plant [TPP], panicles per plant $[\mathrm{PPP}]$, panicle length $[\mathrm{PL}](\mathrm{cm})$, panicle weight $[\mathrm{PW}]$ (g.), spikelets per panicle [SPP], pollen fertility $[\mathrm{PF}](\%)$, spikelet fertility [SF] $(\%)$, test grain weight [TGWT] (g.), grain yield per plant [GYPP] (g.), flag leaf length
[FLL] (cm.), flag leaf width [FLW] (cm.), flag leaf area [FLA] $\left(\mathrm{cm}^{2}\right)$, grain length [GL] (mm.), grain breadth $[\mathrm{GB}](\mathrm{mm}$.$) , grain L/B$ ratio $[\mathrm{GL} / \mathrm{B}]$, kernel length $[\mathrm{KL}](\mathrm{mm}$.), kernel breadth $[\mathrm{KB}](\mathrm{mm}$.$) and kernel \mathrm{L} / \mathrm{B}$ ratio $[\mathrm{K}$ $\mathrm{L} / \mathrm{B}]$.

The mean of the 28 genotypes were analyzed statistically by the method outlined by Ostle (1966). The analysis of variance for different characters was carried out in order to assess the genetic variability among genotypes as given by Cochran and Cox (1950). The level of significance was tested at $5 \%$ and $1 \%$ using $\mathrm{F}$ table values given by Fisher and Yates (1963). Both phenotypic and genotypic coefficient of variability for all characters as estimated using the formula of Burton and De Vane (1953). The broad sense heritability $\left(\mathrm{h}^{2}\right)$ was estimated for all characters as the ratio of genotypic variance to the total or phenotypic variance as suggested by Lush (1949) and Hanson (1956). Genetic advance for each character was estimated by using the formula of Johnson et al., (1955). Genetic advance as per cent mean was categorized as suggested by Johnson et al., (1955).

\section{Results and Discussion}

The mean sum of squares for 21 characters in 28 genotypes under study were presented in Table 1. Analysis of variance revealed highly significant differences among genotypes for all the characters studies indicating the presence of adequate variability among the genotypes.

The estimates of range and mean were presented in Table 2. A wide range of variation was observed in the parental lines of hybrid rice for all the quantitative characters and yield. However, widest range of variability was recorded for spikelets per panicle (119.78-285.37) followed by plant height $(81.64-131.76 \mathrm{~cm})$ and flag leaf area 
$\left(19.56-42.37 \mathrm{~cm}^{2}\right)$. The range of variation obtained for kernel breadth (1.75-2.5 mm), grain breadth $(2.0-3.0 \mathrm{~mm})$ and panicle weight (2.16-3.88 g) was least when compared to all the other characters.

The estimates of genotypic and phenotypic variance components and coefficients of variability (PCV and GCV) were presented in Table 3 and Fig. 1.Variability is essential for wide adaptability and resistance to biotic and abiotic factors and hence, an insight into the magnitude of genetic variability present in a population is of paramount importance to a plant breeder for starting a judicious breeding programme. The phenotypic and genotypic variances measure the magnitude of variation arising out of differences in phenotypic and genotypic values. The absolute values of phenotypic and genotypic variances cannot be used for comparing the magnitude of variability for different characters, since the mean and units of measurement of the characters may be different. Hence, the coefficients of variation expressed at phenotypic and genotypic levels have been used. The relative values of these two types of coefficients give an idea about the magnitude of variability present in the germplasm (Lokesh et al., 2013).

Spikelets per panicle exhibited high genotypic and phenotypic variances, followed by days to $50 \%$ flowering, days to maturity and grain yield per plant. Similar results were obtained earlier by Sawant et al., (1994)and Deb Choudhary and Das (1998).

In general, the values of PCV were higher than the values of GCV indicating that the apparent variation is not only due to genotypes but also due to influence of environment. The estimates revealed that PCV for all characters are slightly more than that of GCV indicating the less influence of environment. Similar results are found by Shobha Rani et al.,
(2001), Subbaiah et al., (2011), and Patel et al., (2014).

The GCV was higher for the characters grain yield per plant (23.843), spikelets per plant (20.98) and flag leaf area (19.288). Hence, these characters are relied upon in stabilized homozygous population and simple selection can be practiced for further improvement. The results are in consonance with Vanisree et al., (2013), Subbaiah et al., (2011), Panwar (2005), Hasib (2005) and in contrast with Yumnam et al., (2011).

The estimates of heritability in broad sense $\left(\mathrm{h}^{2}\right)$ and expected genetic advance (GA) and genetic advance as per cent of mean (GAM) presented in Table 4 and Fig. 2.High heritability (broad sense) estimates $(>60 \%)$ were recorded for all the characters under study indicating characters are least influenced by environment and selection for improvement is rewarding. Highest heritability tillers per panicle (0.99) followed by test grain weight (0.99), kernel breadth (0.99). Similar findings are suggested by Mani et al., (1997), Chand et al., (2005), Panwar (2005), Hasib (2005), Yumnam et al., (2011), Sawarker and Senapati (2014), and Dhanwani et al., (2013); Hasan et al., (2013), found low heritability for spikelet fertility, are in contrast with present findings. Since the estimates of heritability are in broad sense selection based on heritability alone is misleading hence another estimate called genetic advance is used for better prediction of characters under study.

The high genetic advance revealed by characters spikelets per panicle (83.74), followed by plant height (38.07), days to $50 \%$ flowering (13.94) days to maturity (13.43) grain yield per plant (13.14) flag leaf area (12.89) and tillers per plant (11.78) while other yield traits and all grain dimension traits exhibited moderate to very low GA values 
(Table 4). The values of genetic advance as per cent of mean (GAM 5\%) were high $(>20 \%)$ for characters tillers per plant (62.52) followed by grain yield per plant (48.25), spikelets per panicle (42.83), flag leaf area
(39.33), panicles per plant (38) panicle length (36.38), plant height (34.47). However low GAM $(<10 \%)$ were revealed by pollen fertility (5.44).

Table.1 ANOVA for yield and yield contributing characters in rice genotypes

\begin{tabular}{|c|c|c|c|}
\hline Character & $\begin{array}{c}\text { Replication } \\
\text { (d.f=1) }\end{array}$ & $\begin{array}{c}\text { Treatment } \\
\text { (d.f=27) }\end{array}$ & $\begin{array}{r}\text { Errror } \\
(\text { d.f }=27)\end{array}$ \\
\hline DFF & 0.662 & $91.62^{* *}$ & 0.62 \\
\hline DM & 0.092 & $94.32 * *$ & 0.046 \\
\hline PH & 0.053 & $687.72 * *$ & 1.485 \\
\hline TPP & 1.18 & $65.8^{* * *}$ & 0.11 \\
\hline PPP & 3.37 & $18.57^{* *}$ & 0.19 \\
\hline PL & 0.46 & $29.135^{* *}$ & 0.24 \\
\hline PW & 0.17 & $0.4827 * *$ & 0.041 \\
\hline SPP & 83.69 & $3394.59 * *$ & 30.04 \\
\hline $\mathbf{P F}$ & 0.02 & $16.801^{* *}$ & 3.45 \\
\hline SF & 0.036 & $58.737 * *$ & 2.047 \\
\hline TGWT & 0.065 & $7.895^{* * *}$ & 0.039 \\
\hline GYPP & 0.923 & $85.948 * *$ & 1.522 \\
\hline FLL & 2.086 & $30.189^{* *}$ & 0.501 \\
\hline FLW & 0.002 & $0.0244 * *$ & 0.001 \\
\hline FLA & 2.01 & $80.748 * *$ & 0.811 \\
\hline GL & 0.01 & $1.044^{* * *}$ & 0.007 \\
\hline GB & 0.034 & $0.104^{* *}$ & 0.012 \\
\hline GL/B & 0.002 & $0.339 * *$ & 0.001 \\
\hline KL & 0.016 & $0.6154 * *$ & 0.003 \\
\hline KB & 0.012 & $0.053^{* *}$ & 0.002 \\
\hline KL/B & 0.003 & $0.224 * *$ & 0.001 \\
\hline
\end{tabular}

** Significant at $1 \%$ level 
Table.2 Range, Mean for different traits in parental lines of hybrid rice

\begin{tabular}{|l|c|c|c|}
\hline Character & Range & Mean & SE(m) \\
\hline DFF & $88-109$ & 102.03 & 0.312 \\
\hline DM & $116-137$ & 130.03 & 0.416 \\
\hline PH & $81.64-131.76$ & 110.46 & 0.8618 \\
\hline TPP & $9.95-29.35$ & 18.84 & 0.238 \\
\hline PPP & $9.64-22.36$ & 16.26 & 0.308 \\
\hline PL & $14.19-26.45$ & 21.33 & 0.352 \\
\hline PW & $2.16-3.88$ & 3.12 & 0.144 \\
\hline SPP & $119.78-285.37$ & 195.49 & 3.876 \\
\hline PF & $73.56-84.19$ & 79.32 & 1.315 \\
\hline SF & $64.53-88.99$ & 79.82 & 1.0117 \\
\hline TGWT & $13.3-22.22$ & 16.5 & 0.141 \\
\hline GYPP & $16-36.83$ & 27.25 & 0.872 \\
\hline FLL & $21.37-36.09$ & 29.49 & 0.5006 \\
\hline FLW & $1.22-1.66$ & 1.46 & 0.0089 \\
\hline FLA & $19.56-42.37$ & 32.77 & 0.637 \\
\hline GL & $7.02-9.5$ & 7.84 & 7.84 \\
\hline GB & $2.0-3.0$ & 2.42 & 0.026 \\
\hline GL/B & $2.68-4.65$ & 3.25 & 0.026 \\
\hline KL & $5.1-7.5$ & 6.05 & 0.041 \\
\hline KB & $1.75-2.5$ & 2.03 & 0.012 \\
\hline KL/B & $2.44-4.05$ & 3.04 & 0.0227 \\
\hline
\end{tabular}


Table.3 Genotypic and Phenotypic variance components, coefficient of variability for different traits

\begin{tabular}{|l|c|c|c|c|}
\hline Character & $\begin{array}{c}\text { Phenotypic } \\
\text { variance }\end{array}$ & $\begin{array}{c}\text { Genotypic } \\
\text { variance }\end{array}$ & PCV \% & GCV\% \\
\hline DFF & 45.813 & 45.769 & 6.639 & 6.634 \\
\hline DM & 45.741 & 45.713 & 5.205 & 5.205 \\
\hline PH & 344.6 & 343.12 & 16.805 & 16.769 \\
\hline TPP & 32.95 & 32.84 & 30.45 & 30.4 \\
\hline PPP & 9.38 & 9.19 & 18.83 & 18.64 \\
\hline PL & 14.69 & 14.44 & 17.96 & 17.81 \\
\hline PW & 0.26 & 0.22 & 16.407 & 15.03 \\
\hline SPP & 1712.32 & 1682.27 & 21.16 & 20.98 \\
\hline PF & 10.13 & 6.67 & 4.012 & 3.256 \\
\hline SF & 30.392 & 28.345 & 6.906 & 6.669 \\
\hline TGWT & 3.968 & 3.928 & 12.065 & 12.009 \\
\hline GYPP & 43.736 & 42.213 & 24.268 & 23.843 \\
\hline FLL & 15.346 & 14.844 & 13.28 & 13.06 \\
\hline FLW & 0.012 & 0.012 & 7.553 & 7.505 \\
\hline FLA & 40.78 & 39.96 & 19.483 & 19.288 \\
\hline GL & 0.526 & 0.518 & 9.25 & 9.18 \\
\hline GB & 0.052 & 0.052 & 9.434 & 9.434 \\
\hline GL/B & 0.17 & 0.169 & 12.691 & 12.641 \\
\hline KL & 0.303 & 0.306 & 9.182 & 9.132 \\
\hline KB & 0.027 & 0.027 & 8.2 & 8.2 \\
\hline KL/B & 0.123 & 0.122 & 11.52 & 11.47 \\
\hline & & & & \\
\hline
\end{tabular}

Fig.1 Graphical representation of PCV and GCV

DrII \% RTI \%

PCV\%

GCV\% 
Int.J.Curr.Microbiol.App.Sci (2019) 8(9): 879-888

Table.4 Heritability and Genetic Advance for different traits in rice

\begin{tabular}{|l|r|r|r|r|r|}
\hline Character & Heritability & \multicolumn{1}{l|}{ GA } & \multicolumn{1}{l|}{ GA } & GAM & GAM \\
\hline & & $5 \%$ & $1 \%$ & $5 \%$ & $1 \%$ \\
\hline DFF & 0.986 & 13.94 & 17.86 & 13.66 & 17.51 \\
\hline DM & 0.984 & 13.43 & 17.24 & 13.16 & 17.17 \\
\hline PH & 0.996 & 38.07 & 48.79 & 34.47 & 44.17 \\
\hline TPP & 0.997 & 11.78 & 15.1 & 62.52 & 80.13 \\
\hline PPP & 0.98 & 6.18 & 7.92 & 38 & 48.7 \\
\hline PL & 0.98 & 7.76 & 9.94 & 36.38 & 46.62 \\
\hline PW & 0.84 & 0.88 & 1.13 & 28.39 & 36.39 \\
\hline SPP & 0.98 & 83.74 & 107.32 & 42.83 & 54.89 \\
\hline PF & 0.65 & 4.31 & 5.53 & 5.44 & 6.97 \\
\hline SF & 0.93 & 10.59 & 13.57 & 13.26 & 17.04 \\
\hline TGWT & 0.99 & 4.06 & 5.2 & 24.6 & 31.53 \\
\hline GYPP & 0.96 & 13.14 & 16.85 & 48.25 & 61.83 \\
\hline FLL & 0.96 & 7.8 & 10 & 26.46 & 33.91 \\
\hline FLW & 0.98 & 0.22 & 0.28 & 15.36 & 19.68 \\
\hline FLA & 0.98 & 12.89 & 16.52 & 39.33 & 50.41 \\
\hline GL & 0.99 & 0.47 & 1.88 & 18.77 & 24.05 \\
\hline GB & 0.84 & 1.08 & 25.93 & 33.23 \\
\hline GL/B & 0.13 & 1.45 & 18.71 & 23.97 \\
\hline KL & 0.93 & 0.43 & 16.89 & 21.64 \\
\hline KB & 0.91 & 23.53 & 30.16 \\
\hline
\end{tabular}


Fig.2 Graphical representation of $\mathrm{h}^{2}$ and Genetic advance (5\%)

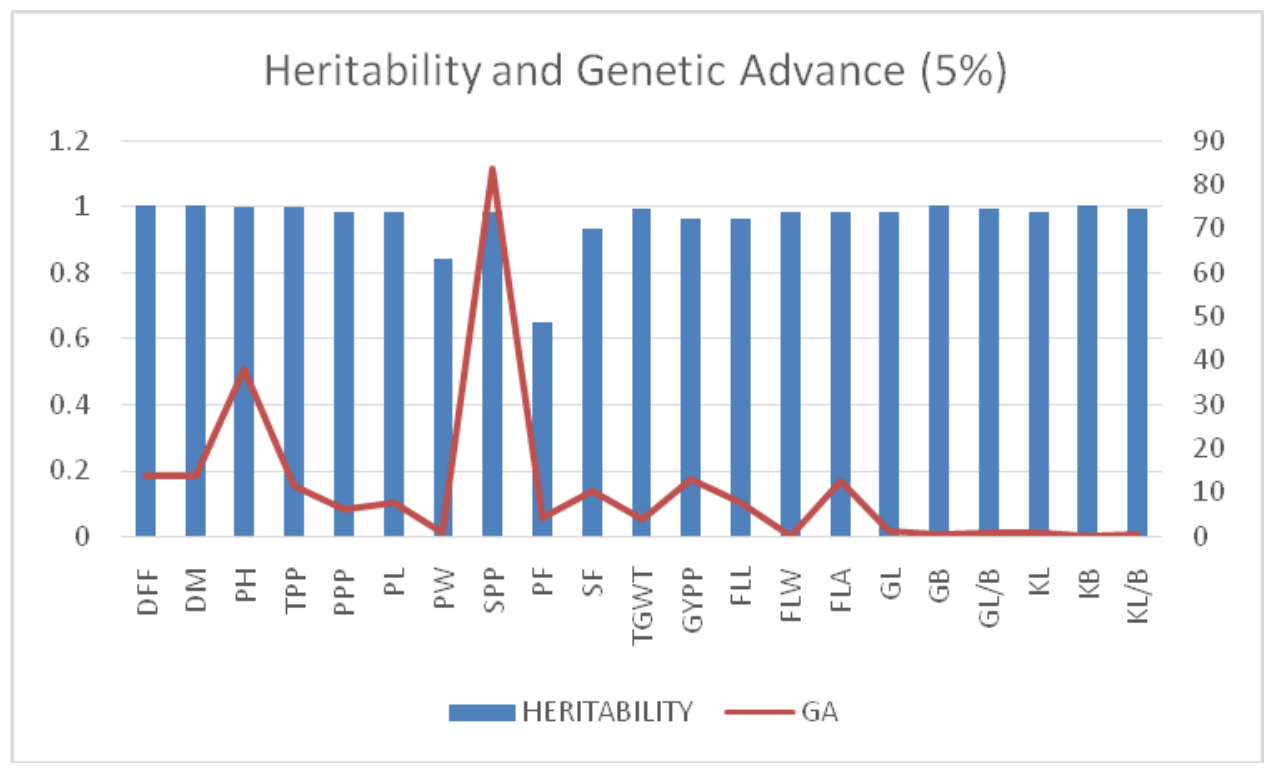

Heritability should be considered along with genetic advance as per cent of mean, however it is not necessary that character showing high heritability will also exhibit high genetic advance (Johnson et al., 1955). High heritability coupled with high GAM was observed with tillers per plant grain yield per plant, spikelets per panicle, flag leaf area, panicles per plant, panicle length, plant height, panicle weight, flag leaf length, grain $\mathrm{L} / \mathrm{B}$ ratio, and test grain weight are governed by additive genes and improvement is rewarding. Similar kind of results were obtained by Tirumala rao et al., (2014) Dhanwani et al., (2013), Vanisree et al., (2013), Babu et al., .(2012). However, low GAM for days to $50 \%$ flowering was reported by Sawarker and Senapati (2014), Tirumala rao et al., 2014, Seyoum et al., (2012) and Kole et al., (2008); low GAM for grain yield per plant was reported by Venkanna et al., (2014) and Kole et al., (2008); low GAM for panicle length was reported by Babu et al., (2012), Seyoum et al., (2012), Subbaiah et al., (2011) and Kole et al., (2008); moderate GAM for days to $50 \%$ flowering, plant height and low GAM for panicle length, spikelet fertility, days to maturity, test weight, grain yield per plant are reported by Hasan et al., (2013).

High heritability coupled with moderate GAM was observed for characters days to 50 $\%$ flowering, days to maturity, spikelet fertility, flag leaf width, grain length, grain breadth, kernel length and kernel breadth indicating characters governed by additive genes though influenced by environment. Similar findings are reported by Allam et al., (2015), Patel et al., (2014), Dhanwani et al., (2013), Vanisree et al., (2013), Subbaiah et al., (2011).

However Babu et al., (2012) and Subbaiah et al., (2011) reported low GAM for kernel breadth; Sawarker and Senapati (2014) reported low GAM for days to maturity. High heritability coupled with low GAM is observed for the character pollen fertility (table 4) indicating the character is highly influenced by environmental effects and selection would be ineffective. From the present study, it is evident that genotypes studied may provide good source of material for further breeding programme. Therefore, the information on the genetic parameters 
such as coefficient of variation, heritability, genetic advance can help the breeder to evolve high yielding cultivars.

\section{Acknowledgement}

Authors are thankful to Council for Scientific and Industrial Research (CSIR) for financial assistance as JRF [grant no: 09/271(0093)/2016-EMR-I] for fulltime doctoral degree programme at University of Agricultural Sciences, GKVK, Bangalore 65.

\section{References}

Allam, C.R, Jaiswal, H.K, Qamar, A, Venkateshwarlu, $\mathrm{C}$ and Reddy, Y.S. 2015. Variability, heritability and genetic advance studies in some indigenous genotypes of basmati rice (Oryza sativa L.). Electron. J. Plant Breed.,6(2): 506511.

Babu V.R, Shreya K, Dangi K.S, Usharani G and Nagesh P. 2012. Genetic variability studies for qualitative and quantitative traits in popular rice hybrids of india. Internat. J. Scientific and Res. Public., 2(6) ISSN: 2250-3153

Burton , G.W. and Devane, E.M. 1953. Estimating heritability in fescue (Festucaarundinaceae) from replicated clonal material. Agron. J., 45: 478-481

Chand, U., Katoch, P.C. and Vijay Kumar. 2005. Variability studies in some macromutations induced by EMS and gamma rays in Basmati rice T-23. Annals of Biol., 21(2): 137-141.

Cochran, G. W. and Cox, M.G. 1950. Experimental designs. John wiley and sons, Newyork.

Deb Choudhary P.K. and P.K. Das Genetic variability, correlation and path coefficient analysis in deep water rice. Ann. of Agric. Res. 19(2): 120-121 (1998).

Dhanwani, R.K, Sarawgi, A.K, Solanki, A, and Tiwari, J.K. 2013. Genetic variability analysis for various yield attributing and quality traits in rice (Oryza sativa L.) The BioScan, 8(4): 1403-1407.

Falconer, D.S. 1981. Introduction to quantitative genetics. 2ad edition. Oliver and Boyd, Edinburg, London.

Fisher, R.A. and Yates, F. 1963. Statistical tables for biological, agricultural and medical research. Oliver and Boyd, London

Hamdi, A. 1992. Heritability and combining ability of root characters in lentil (Lens culinarisMedik), Egyptian J. Agric. Res., 70(1): 247-255.

Hanson, C.H, Robinson, H.F. and Comstock, R.E. 1956. Biometrical studies of yield in segregating populations of Korean lespedza. Agron. J., 48(6): 268-272.

Hasan, M.J, Kulsum, M.U, Akter, A, Masuduzzaman, A.S.M and Ramesha, M.S. 2013. Genetic variability and character association for agronomic traits in hybrid rice (Oryza sativa L.) Bangladesh J. Plant Breed. and Genet., 24(1): 45-51.

Hasib, K. M. 2005. Genetic variability, interrelations and path analysis for panicle characters in scented rice. Crop Res., (Hisar) 30(1): 37-39.

Johnson, H.W, Robinson, H.F. and Comstock, R.E. 1955. Estimates of genetic and environmental variability of soybeans. Agron. J., 47: 314-318.

Kole, P.C, Chakraborty, N.R. and Bhat, J.S 2008. Analasis of variability, correlation and path coefficients in induced mutants of aromatic non-basmati rice. Tropical Agric. Res. and Extension, 11: 60-64.

Lokesh, B, Reddy, P.S, Reddy, R.V.S.K. and Sivaraj, N. 2013. Variability, heritability and genetic advance studies in Brinjal (SolanummelongenaL.) Electron. J. Plant Breed.,4(1): 1097-1100.

Lush, J.L. 1949. Heritability of quantitative characters in farm animals. Proceedings 
of 8th congress of genetics, Heriditas., 3(1): 356-375.

Mani, S.C, Verma, S.K. and Sharma, R.K. 1997. Genetic variability and character association for panicle traits in Basmati rice. Agric. Sci. Digest, 17(3): 155-157.

Ostle, B. 1966. Statistics in research 1st edition, Oxford and Indian Book House Private Limited, New Delhi. Paikhomba, N, Kumar, A, Chaurasia, A.K. and Rai, P.K. 2013. Assessement of genetic parameters for yield and yield components in hybrid rice and parents. $J$. Rice Res., 2(1): 117.

Panwar, L.L. 2005. Genetic variability, heritability and genetic advance for panicle characters in transplanted rice. Res. on Crops, 6(3): 505-508.

Patel, J.R, Saiyad, M.R, Prajapati, K.N, Patel, R.A. and Bhavani, R.T. 2014. Genetic variability and character association studies in rainfed upland rice (Oryza sativa L.) Electron. J. Plant Breed.,5(3): 531-537.

Sawant D.S., S.L. Patil and S.G. Bhave Variability, heritability and genetic advance in pure lines of lowland rice. Annals of Agric. Res. 15(1): 27-30 (1994).

Sawarkar, A. and Senapati, B.K. 2014. Polygenic variations and cause effect relationship in some photo-insensitive recombinant inbred lines (RIL's) of Basmati derivative. African $J$. Biotechnol., 13(1): 112-118.

Seyoum, M, Alamerew, S and Bantte, K. 2012. Genetic variability, heritability,correlation and path analysis for yield and yield related traits in upland rice (Oryza sativa L.) J. Plant Sci., 10: 3923/jps.2012.

Shobha Rani, N., Rama Prasad, A. S., Prasad, G. S. V., Bhaskara Reddy P. and Krishna Veni, B. 2001. Genetic variability for yield component in aromatic and quality rice germplasm. Indian J. Plant Genet. Resource , 14: 206-209.

Subbaiah, P.V, Sekhar, M.R, Reddy, K.H.P. and Reddy, N.P.E. 2011. Variability and genetic parameters for grain yield and its components and kernel quality attributes in CMS based rice hybrids (Oryza sativa L.) Internat. J. Appl. Biol. and Pharmaceutical Technol., 2(3): 603-609.

Tirumala rao, V, Mohan, Y.C, Bhadru, D, Bharithi, D. and Venkanna,V. 2014. Genetic variability and association analysis in Rice. Internat. J. Appl. Biol. and Pharmaceutical Technol., 5(2): 6365.

Vanisree, S, Anjali, K, Damodar Raju, CH, Surender Raju, CH, and Sreedhar, M. 2013. Variability, heritability and association analysis in scented rice. $J$. Biological Sci. Opinion, 1(4): 347-352.

Venkanna, V, Lingaiah, N, Raju, CH.S, and Rao, V.T. 2014. Genetic studies foe quality traits of $\mathrm{F} 2$ population in rice (Oryza sativa L.). Internat. J. Appl. Biol. and Pharmaceutical Technol., 5(2): 125127.

Yumnam, S, Nandeshwar, B.C, BijanAdhikari, Senapati, B.K. 2011. Variability and Character association in recombinant lines F6 of basmati derivative. Curr. Advan. in Agric. Sci., 3(1): 24-28.

\section{How to cite this article:}

Chinnapa Reddy Allam, T.E. Nagaraja and Shivakumar, N. 2019. Studies on Variability, Heritability and Genetic Advance in parental lines of Hybrid Rice (Oryza sativa L.). Int.J.Curr.Microbiol.App.Sci. 8(09): 879-888. doi: https://doi.org/10.20546/ijcmas.2019.809.105 